\title{
Café Pacific and online censorship in Fiji
}

A commentary on how, more than a decade after the military coups, a hangover from the post-coup 1990 Constitution of Fiji cast a shadow on the media and journalism education methodology in 1998, in spite of the new "free speech" 1997 Constitution.

\section{By DAVID ROBIE}

USE of the Internet as a news media resource in the Pacific was pioneered by the University of Papua New Guinea in 1996 with an online newspaper and archives website. Activity has since moved to the University of Hawai'i-East West Centre, with its Pacific Islands Report news site, and the University of the South Pacific's regional Pacific Journalism Online. Over the past two years, there has been a proliferation of newspapers on line in the Pacific, initially in Papua New Guinea where all three of the country's English-language papers are now on line. The value of news websites were realised by the PNG media which "gained high profiles internationally, especially during the Sandline mercenary crisis and its aftermath" (Robie ,1997: 61)

News websites have been developed in many locations in the Pacific, including American Samoa, Cook Islands, French Polynesia, Vanuatu and New Zealand, where an online Tongan newspaper is produced. However, in Fijithe second major news industry nation of the region - the print media and most other media have been slow to use the medium. There has also been more overt political pressure in Fiji - even from other news media quarters - to curb or control independent news and research websites. A controversy in August 1998, described by some as the first "freedom of the Internet" case in the region, surfaced, ironically just four weeks after the country's new Constitution took effect on 27 July 1998. The constitution guarantees freedom of expression and 


\section{ONLINE CENSORSHIP}

the press along the lines of Article 19 in the Universal Declaration of Human Rights.

This article examines the background to the controversy and the media dilemmas it poses to a country where freedom of speech has remained sensitive and, at times, fragile ever since the military coups of 1987 . It also examines the implications for the region in terms of truth, fairness and balance, and the future of journalism training and education.

\section{Truth, expediency and 'radical pluralism'}

Online publishing represents one of the most dramatic adoptions of new media technology in history. When cyberspace is compared to past technological revolutions such as the growth of the penny press in the 1830 s and the 1880 s, or the rise of radio in the late 1920 s and then the emergence of television in the 1950s, "more people have gained access to the World Wide Web in a shorter period of time than have adopted any new media in previous history (Reddick and King, 1997: 222). Online journalism shares with the Web its main characteristics, such as immediacy and interactivity, "making more real every day the global village of Marshall McLuhan" (Dufflos, 1998: 79). The advantage of online information over traditional print media is primarily its immediacy. A second factor is the ability to download files, news archives and other information stored by online services. Finally, the interactivity of online media eliminates, to a degree, the invisible barrier separating readers from reporters and editors in traditional newspapers.

In a region like the South Pacific, with vast distances, few news media organisations with limited resources, and the high cost of telecommunications, online news media services offer many advantages. Commenting on the lack of awareness and enthusiasm for the technology by some news media executives and even academics, Australian media academic Stephen Quinn says:

The future of journalism lies in the digital realm. It is vital that journalists in the Pacific be taught how to publish and research on the Internet, and about the design of Web sites. Editors and publishers who are sceptical about the value of such courses need to wake up and, as the American say, "smell the coffee" - join the late 20th century. Otherwise they risk allowing their staff to be left behind in a form of technological dark ages (1998). 


\section{DAVID ROBIE}

According to the International Federation of Journalists, as well as online editors developing their own writing style, the digital newsroom is evolving with its own rules: "That is why the IFJ regards the modernisation of the teaching techniques of journalism as a major challenge in coming years" (Dufflos, 1998: 79). This is a challenge that tertiary journalism education in the Pacific has accepted with enthusiasm.

Both online technology and the culture of "virtual communities" encourage individuals to speak out more frequently and to become involved in the public life of their communities. They are likely, as Mike Godwin argues, to engage in what he labels "radical pluralism" - a kind of public participation which could characterise political life in the new millennium (1998: 54). The power of the Internet, and the alternative views that it enables, has become an international concern for power élites, including those in the Pacific. If the Soviet Union was brought down by the fax machine, argues Robert Hooper, a former Fulbright scholar at the University of the South Pacific, Malaysia's "transition to new leadership will be driven by the Internet. What we are witnessing is the emergence of a modern nation that has outgrown the leadership of its creator" (Hooper, 1998).

But what about truth, reliability, ethics and accountability? Will the new media be any more dependable or equitable for the public? Goldstein, in The News At Any Cost - a book about compromised ethics and fabricated or distorted stories in the news media - tells of his experiences of "pack journalism at its worst. Rather than operate independently, the reporters were cliquish. They could be easily manipulated, and they could also be petty and unreasonable" (1984: 14). He cites examples of how such pressures produce distorted journalism in the United States, including Time magazine's libel against Ariel Sharon by publishing a paragraph falsely linking him to a 1982 massacre of Palestinian refugees in Beirut; a longtime writer at the New Yorker admitting to having invented characters and rearranged conversations; and the case of a Washington Post writer who won a Pulitzer Prize in 1980 for a story about an eight-year-old heroin addict, Jimmy, who was later found to have been fabricated.

More recently have been the Stephen Glass and Patricia Smith debacles among several in the United States which have further eroded public confidence in media credibility. In their 29 June 1998 issue, after discovering that 27 of 41 articles written by Glass, a prolific and widely read columnist, were either partly 
or totally bogus, the editors of New Republic told their 95,000 readers: "We offer no excuses for any of this. Only our deepest apologies to all concerned." Barely a week earlier, the Boston Globe's popular columnist Patricia Smith also rounded off her final column with an apology: "From time to time in my Metro column, to create the desired impact or slam home a salient point, I attributed quotes to people who didn't exist. I could give them names, even occupations, but I couldn't give them what they needed most - a heartbeat." (Chicago Tribune, 1998).

The Pacific region also has examples. In the mid 1980s, New Zealand's Sunday Times published a major article on the guerrilla struggle in Afghanistan with pictures and text later being found to be a fabrication. In 1994, the Auckland media fraternity was split by a bitter defamation case between two leading journalists. Metro magazine was sued by Sunday Star-Times columnist, Toni McRae, for $\$ 550,000$ over a description of her as being "regularly pissed" in the magazine's Felicity Ferret gossip column. It was apparently a play on the name of her column, Pssst. The magazine's editor, Warwick Roger, one of the country's leading investigative journalists, admitted that he had invented the drink idea (she didn't drink) and he knew it was "quite a sin" for a journalist to invent things (New Zealand Herald 1994). After winning the case, Ms McRae settled for $\$ 150,(0)(0)$ in damages.

Similar slanging matches between prominent journalists in the Pacific are perhaps best represented by the sacking in 1992 of Johnson Honimae by the Solomon Islands Broadcasting Commission (over his freelance reporting on Bougainville for international media). At the time he was SIBC's head of current affairs and correspondent for Radio New Zealand International.

The affair led to the resignation of Patterson Mae (then general manager of SIBC) as president of the Pacific Islands News Association in the face of protests from Pacific colleagues who accused him of undermining the principles of press freedom (The Word, 1992). It was less than a year after PINA had been at the centre of controversy over an invitation to the 1987 Fiji military coup leader, Brigadier-General Sitiveni Rabuka, to be guest speaker at its conference in Auckland. The New Zealand venue for the conference was an act of selfcensorship as well as a response to the repressive approach to the media by the régime back home in Suva, where PINA's offices are located.

Dykes Angiki, SIBC's news editor and president of the PINA affiliate, Media Association of the Solomon Islands, wrote a column in the Solomon Star, defending the sacking of Honimae, saying it was not suppression of media 


\section{DAVID ROBIE}

freedom (Angiki, 1992). He claimed his former colleague had been axed because he was "stringing" for overseas news services, a common and legitimate practice among many journalists. Stringers, Angiki argued, meant representing "foreign interests". Honimae responded in the Star by accusing Angiki of "hypocrisy and envy", adding that the SIBC wanted staff "who can be led by the nose". (Honimae, 1992).

The power of the Internet and alternative views to disrupt governments has become an international concern for those élites in power, even in the Pacific, where sensitivities have been particularly strong in the Fiji Islands. In comparisons with at least one African country, Zambia, concerns by authorities over website content led to a siege of a newsroom .and arrests of journalists. Zambia's The Post has long had an outspoken presence on the Internet and its reports have troubled authorities. The state-controlled Daily Mail challenges its independent rival's cyberspace view of events in the country. Information and Broadcasting Minister Newstead Zimba claimed the Post's Internet presence was "damaging Zambia's image globally ... splashing a wrong impression [of the country] all over the world". But editor-in-chief Fred M'membe replied that unlike "other journalists working for Government mouthpieces, we are not public relations officers whose only discernible occupation is to portray a good image of the Government" (Hampande, 1998).

Friction also exists within the Pacific media, and is likely to increase with the expanded use in the region of cyberspace technology. This is evident in a controversy in Fiji in 1998 over Internet publishing which involved threats to withdraw work permits for foreign media academics. The controversy occurred at a time when Fiji was preparing for its first genuinely democratic election since the coups.

\section{The controversy over Café Pacific}

The following is background to the controversy:

27 August 1998: The Fiji Times published a report, written by reporter Margaret Wise, alleging that the Fiji Government was investigating complaints that both New Zealand journalism academics at the University of the South Pacific - the entire fulltime staff of the programme - had breached their work permit conditions. The inquiry was said to be directed towards revoking their permits ${ }^{1}$. It apparently focused on a report on David Robie's Café Pacific/AsiaPacific Network, an Internet news, commentary and current affairs website: www.asiapac.org.fj/cafepacific/resources/aspac/pacmedia.html The website was first es90 PACIFIC JOURNALISM REVIEW 6:1 2000 


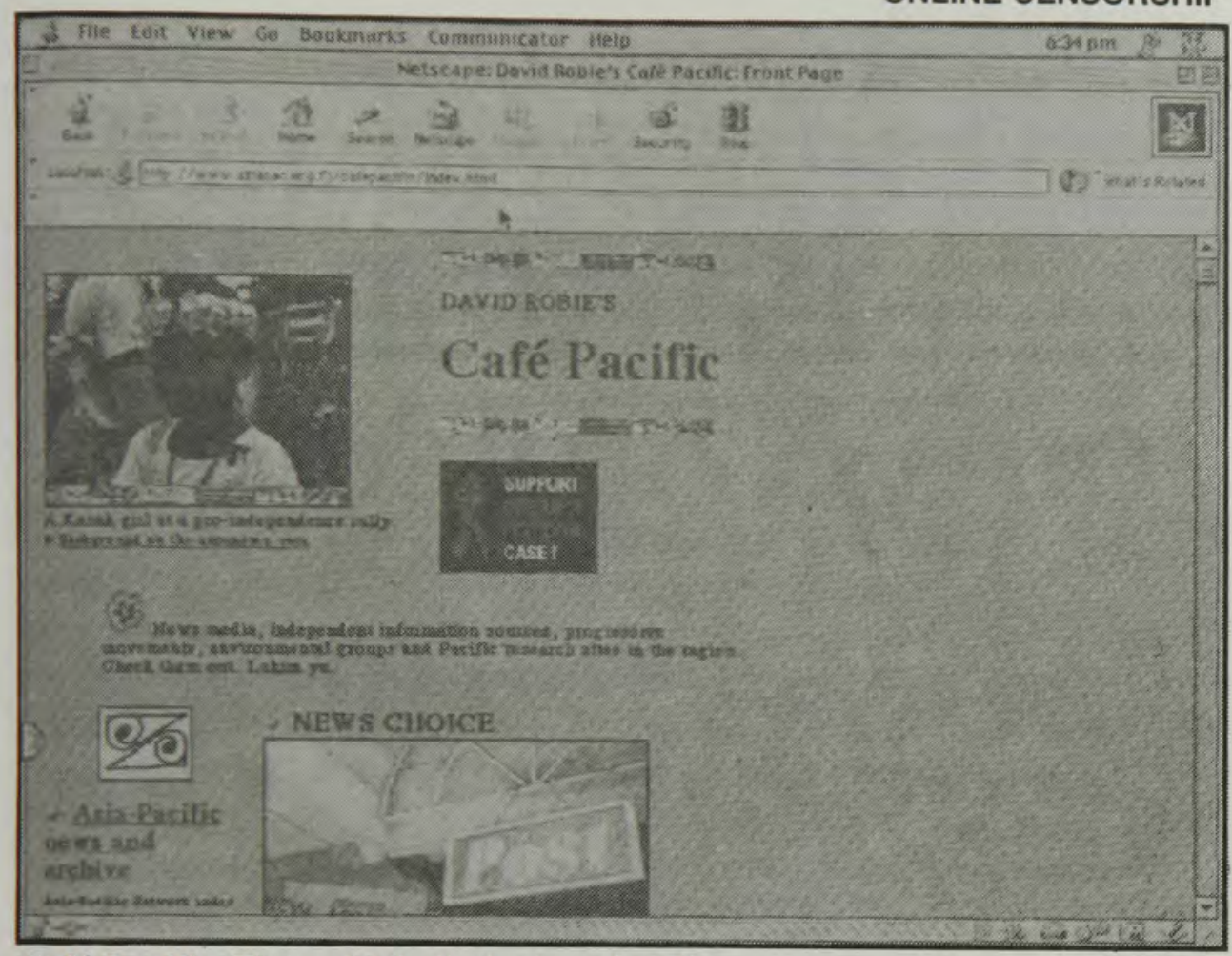

Café Pacific: The website that caused a stir.

tablished at the University of Technology, Sydney, in 1996. It is independent of the USP training website, Pacific Journalism Online, but is linked to it. The story provided an overview of South Pacific news media and criticised Fiji Government plans to legislate for a Media Council to replace the independent and self-regulating council already in place (Reportage Media Magazine, 1998). Complaints were also said to be against Ingrid Leary over her weekly Media Watch column in Fiji's Daily Post and tutorials conducted at the Fiji Institute of Journalism. The Fiji Times report claimed that the two media academics were "using their positions at the USP to lend authority to their work outside it". Citing an unnamed ministry source, the article added:

"We have copies of articles written by Robie that features on the website," the source said.

"Their work permits were granted very reluctantly because of protest by locals earlier this year so they should respect the conditions of the permits." 


\section{DAVID ROBIE}

He was referring to an article by Mr Robie on August 9 titled "Pacific press freedom on the rocks".

The first paragraph said that Fiji's "first genuinely democratic election" since the coups would take place next year.

The article also said that in the appointment of a Media Council, Government was seeking "ways to muzzle the news media in spite of the new Constitution's guarantee of freedom of speech and information". Government had delayed issuing the work permits earlier this year following protests from some members of the local media industry (Fiji Times 1988a).

28 August: Margaret Wise again reported similar claims against Leary and Robie. This time her report quoted the Home Affairs Ministry's Permanent Secretary, Emitai Boladuadua, as saying the Government "would withdraw the work permits [of the two staff] if they were found to have breached the terms under which they were given" (Fiji Times, 1998b). The Secretary said some Government departments and some "members of the public" had made "complaints". Wise never interviewed Robie or Leary.

The same day an official statement was issued by USP Registrar, Sarojini Pillay, stating the two lecturers were not breaching their work permits. She added that their activities were within the normal roles of research and publication carried out by academics. The Head of Department, Professor Subramani, also commended the lecturers, saying they were doing "outstanding" work. This statement was widely published and broadcast in the other Fiji news media, but was not published by the Fiji Times. In another statement, the president of the USP Staff Association, Dr Ganeshwar Chand, said the journalism lecturers had "perfect freedom" to carry out research and publish in areas of their expertise (Chand, 1998).

31 August: The Fiji Times published the author's letter criticising the newspaper for "blatant bias" (Robie, 1998b). Ironically, the Fiji Times also published an editorial the same day, entitled "A draconian response", in support of the lecturers and the principle of academic freedom ${ }^{2}$. It said that when academic research involved journalism "anything published takes on a more sensitive aspect as far as officialdom is concerned". The editorial argued that if there had been a breach, "the threat to withdraw their work permits is far too draconian a response" (Fiji Times, 1998c).

Jone Dakuvula, a former press secretary to Prime Minister Rabuka, stressed 


\section{Fiji presses for work ban to}

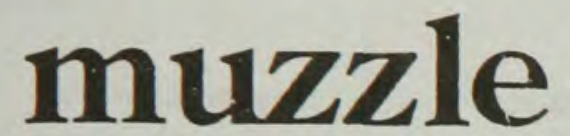

By JOHN MANUKIA and NZPA

Fijian politicians are continuing to apply pressure to have work permits revoked for two Suva-based New Zealand journalism lecturers over alleged breaches of their permits.

But there is mounting international support for David Robie and Ingrid Leary from media organisations, human rights advocates and academics.

The pair, who attracted strong opposition from local media people when they took on lecturing jobs at the University of the South Pacific this year, have been accused of going outside the boundaries of their work permits by writivis articies in local newspapers and on the Internet.

Many observers see the situation as a "test issue" for the nation's new constitution, particularly a clause referring to freedom of expression.

The Information Minister, Filipe Bole, has told the Fiji Senate that Mr Robie was breaching his work pernit by writing news reports on his Internet Website:

Ingrid Leary is under attack for teaching journalism part-time at the Fiji Journalism Institute. which is run by local journalists, and for writing a weekly column in the Daily Posl.
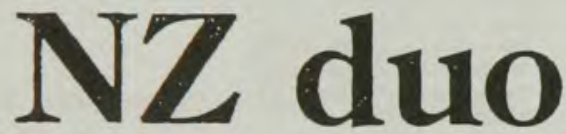

However, the university said that both journalists were required by the university to write articles for publication.

The registrar, Sarojni Pillay, said university acadenic staff "have the perfect freedom to carry out academic research and publish it ..."

In editorials, Fiji's two daily newspapers, the Fiji Times and the Daily Post, condemined the attacks on the New Zealand journalists. The Times said it was draconian.

Support for the pair has come from the New Zealand Journalists Training Organisation (JTO), the Association of University Staff in New Zealand, Parific Media Walch in Sydney and the Tahiti Pacifigue Magazine.

The clief executive of the JTO, Bill Southworth, said the harassment of the two lecturers was disappointing.

"Perhaps those who wish to silence Robie and Leary should take time to read Fiji's new constitution. Section 30 says every person has the right to freedom of expression, including the freedom to receive and impart ideas."

Ingrid Leary said her newspaper column was what academics would label a conservative one that pushes the theme of media responsibility. 


\section{IFEX action alert service}

International Freedom of Expression Exchange Clearing House

\section{ACTION ALERT}

\section{Originator: Reporters sans frontieres (RSF)}

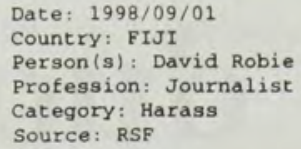

\section{New Zealand journalists threatened to have work permits revoked}

(RSF/IFEX) - According to RSF, David Robie, a journalism coordinator at the regional University of South Pacific based in Suva, Fiji, and correspondent of Reporters Sans Frontières for the last four years, and Ingrid Leary, a journalism lecturer, have been threatened with having their work permits revoked because of what they wrote as journalists and academics. They are both New-Zealand nationals.

It seems that the threat came after an article was published on David Robie's web site, which criticised the Fiji government's plan to legislate for a media council to replace the independent and self-regulating council already in place.

David Robie is the publisher of an independent Internet website dedicated to press freedom and journalism issues. Ingrid Leary writes a weekly "Media Watch" column for the Fiji newspaper "Daily Post".

\section{Pecommended Action}

Send appeals to authorities:

- to ensure that David Robie and Ingrid Leary can exercise their work freely without fear of pressure, as the new Fijian constitution allows

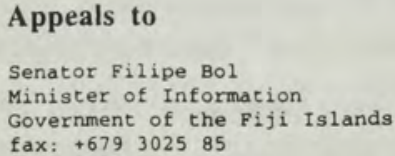

Please copy appeals to the source if possible.

\section{More information}

For further information, contact Manuel Jardinaud at RSF, 5, rue Geoffroy Marie, Paris 75009, France, tel: +33 I 44838484, fux: +33 I 4523 II 51, e-mail: asie@ rsf.fr Internet: http:I/www.rsf.fr

The information contained in this alert is the sole responsibility of RSF. In citing this material for broadcast or publication, please credit RSF.

Distributed by the International Freedom of Expression eXchange (IFEX) Clearing House.

489 College St., suite 403 , Toronto, ON, Canada M6G 1 A5

Tel: +1 +165159622 Fax: +1 4165157978

E-mail: ifex@ifex.org

Internet site: hitp://www.jex,org/ 
in a letter to The Sunday Times that under the new Fiji Constitution [Section 30 (1)]:

Every person has the right to freedom of expression, including: Freedom to seek, receive and impart information and ideas; and Freedom of the press and other media.

He added:

Reading from your report, it appears to me that some local news media employees or journalists were involved in these complaints, which seem to be based mainly on these persons' disagreements with either the views of David Robie and Ingrid Leary, or the fact that they have been lawfully employed by USP.

Our new Constitution has been in force for barely one month and here we have some news media people attempting to suppress two well-qualified journalists' freedom of expression, perhaps in the hope that they could be expelled from this country for the "crime" of writing, publishing and teaching journalism.

Where is the Fiji journalists' much vaunted Code of Ethics? (Dakuvula, 1998).

1 September: In a letter published in both the Fiji Times and the Daily Post, Assistant Information Minister, Ratu Josefa Dimuri, confirmed the Ministry had "received complaints from both local journalists and regional media organisations who were of the view that their interests were being jeopardised by the involvement of these two people in other areas of work not stipulated in their work permits" (Dimuri,1998). The same day, Information Minister Senator Filipe Bole was reported in the Daily Post as having used parliamentary privilege to allege in the Senate the day before that Robie was serving a "dual role" in the University of the South Pacific. He claimed that Robie was feeding his own company in Auckland with information from the Internet. Senator Bole added: "There is a distinct role between being a lecturer and a journalist. (Daily Post, 1998). The author wrote to the Minister the same day saying he had never earned any income from websites, all his work was education-related at the university and he had no business interests in Fiji ${ }^{3}$. No acknowledgement was received from the Senator. 


\section{DAVID ROBIE}

A Daily Post editorial commended the journalism lecturers for improvements made in a short time. The newspaper said that in the past, when the USP program had been established with French Government aid funding, "it was never as good as it should have been":

However, since the appointment of Mr Robie and Ms Leary, things have changed. There is now realistic practical work being done, and students, for the first time, are on attachment to newsrooms. Now the students are more involved in technological developments, especially with the Internet. These things are possible because Mr Robie and Ms Leary bring into the program a wide mix of practical and theoretical experiences.

Mr Robie is one of the region's most outstanding journalists, who, apart from having written [seven] books, has covered issues in most Pacific Islands. Ms Leary is an experienced newspaper and television journalist. Her forte, however, is law, an area crucial to journalism in a developing country like Fiji (Daily Post, 1998b).

The editorial added:

The saddest thing is the deafening silence from the Pacific Islands News Association and the Fiji Media Council. By failing to support the rights of journalists, like Mr Robie and Ms Leary, whether they be teachers, students or whatever, these organisations are helping to destroy the very freedom of expression they have so often said they protect.

International reaction criticising the pressure started to flow (New Zealand Herald, Evening Post, Tahiti-Pacifique, 1998). The Paris-based media freedom group Reporters Sans Frontières wrote to Senator Bole protesting against the harassment and asking that the lecturers be allowed to work freely without fear of pressure, as the new Fiji Constitution allowed (RSF, 1998). The New Zealand Journalists Training Organisation executive director, Bill Southworth, a former editor of the now closed Fiji Sun, said those in the media who were complaining about the work permit issue should "take time to read Fiji's new Constitution." Commonwealth Fellow in Human Rights Education Caren Wickliffe, a Ngati Porou lawyer from Aotearoa/New Zealand, said the promotion and protection of Article 19 "is considered fundamental to achieving participatory democracy", adding that she supported the program's "contribution to the development of media and journalism in the Pacific" (Wickliffe, 1998). 


\section{DAVID ROBIE}

Post and PINA members. This complaint led to an apology for misrepresentation by the Daily Post ${ }^{1}$.

5 September: The author publicly exposed the attempts to suppress free expression in Fiji with a commentary on the web entitled "The gag attempt on Café Pacific". www.asiapac.org.fi/cafepacific/resources/aspac/gag.html 8 September: The Information Minister, Senator Filipe Bole, finally made it clear that there was no foundation to the allegations when he told reporters no investigation was being carried out (Daily Post, 1998b). The case was dropped.

\section{Conclusion}

Cyberspace media, with its attendant possibility of radical pluralism, now give both developed and developing nations the opportunity to achieve the objectives of Article 19 of the Universal Declaration of Human Rights which states that: "Everyone has the right to freedom of opinion and expression; this right includes freedom to hold opinions without interference and to seek, receive and impart information and ideas through any media and regardless of frontiers."

Too often in the South Pacific, lip service is paid to these ideals. On the one hand, political leaders, and even some prominent journalists, espouse these goals and declare themselves in support of free expression and free media. But on the other hand, as soon as some aspect of the media becomes challenging, "Western" values are condemned as undermining "traditional" values, or news media freedom is denounced as a "foreign flower".

In spite of the rhetoric about Fiji having a "free media" and notwithstanding some news media organisations "testing the limits" over selected issues, there is no doubt that the national news media have suffered from a loss of professionalism, erosion of ethics and a debilitating parochialism in the years following the military coups. The reporting of the work permits issue is a striking example of trial by publicity. In the end, the accusers' attempt at censorship was dropped.

In Ingrid Leary's Media Watch column, she writes about poor news practices and ethical lapses taken for granted in some media organisations. Perhaps the cynicism of some Fiji readers is well summed up by the following comment in a letter to the editor of two daily newspapers:

There has been a lot of debate over media freedom in Fiji. Freedom to report is an essential right, I agree.

But, does freedom give a television crew the right to follow a disturbed man around as he is ejected from a boxing match and then broadcast to 
a the nation for what seemed an embarrassingly (for the TV station) long time?

Is it freedom to label someone a "madman" in banner headlines on the front page of a daily newspaper? And, to rub salt into an already raw wound, poke fun fun at him in a cartoon.

Where is your compassion people? I believe the media owe this gentleman and his family an apology (Samson, 1998).

Media education, both for practitioners and officialdom, will be needed and tertiary journalism courses such as the University of the South Pacific's program have an important role to play in raising professional standards and credibility. Cyberspace news sites such as Café Pacific and Pacific Journalism Online and the improved research and computer-assisted reporting inquiry techniques they help introduce, are also a part of this strategy of new technology for democratisation and freedom of expression in Pacific media.

As Robert Pullan, founding president of Australia's Free Speech Committee, notes, all fights about censorship are fights about power: "At some level we know instinctively that censorship is disreputable. Often, as we will see it, the censor disguises itself simply by denying that what it is doing is censorship. At the same time, the censor says its strongly favours free speech and adds a daunting reminder of the power of words" (Pullan, 1994).

\section{Notes:}

1. During November-December 1997, the Daily Post published five unsigned articles purporting to be "news" but which was actually unsubstantiated and unsourced attacking David Robie's appointment to USP. One article (December 23) claimed that the Prime Minister's Office was investigating his appointment: "Mr Robie wrote a series of articles attacking the 1987 coups. He accused international and Fiji journalists of being propagandists and apologists for the Rabuka regime." This misrepresents a passage entitled "A compromised media" in the author's book, Blood on their Banner: Nationalist Struggles in the South Pacific (Zed Books, London, 1989, pp 238-241. The author filed a formal complaint with the Fiji Media Council against the biased and unbalanced articles in the Daily Post, Sunday Post and against two PINA officials. The Daily Post published an apology for the misrepresentations on November 30,1998, following mediation by the council.

2. Editor-in-chief Russell Hunter told the author on August 30 that he had planned to write the editorial before he received the letter of complaint about bias.

3. The author has a small publishing company which was established in New Zealand 


\section{DAVID ROBIE}

in 1984, but it has no connection with Fiji. Both ministers, Ratu Josefa Dimuri, and Senator Filipe Bole, lost their parliamentary seats in the May 1999 general election.

\section{References:}

Angiki, Dykes (1992). "Sacking of a journalist not suppression of media freedom", Solomon Star, April 3.

Chand, Dr Ganeshwar (1998). Open letter from the president of the USP Staff Association to the USP Registrar.

Chicago Tribune (1998), cited in "Telling it like it isn't",Reportage Media Magazine, Spring, pp 6-7

CPU News (1997). "PNG journalism surfs on the Net", November 1997.

Crozier, Rob (1998). Letters by the executive director of the NZ University Staff Association (NZUSA) to Prime Minister Sitiveni Rabuka and Information Minister Filipe Bole, September 3.

Dakuvula, Jone (1998). Letter to the editor, The Sunday Times, August 30; Daily Post, August 31 .

Dimuri, Ratu Josefa (1998). Letter to the editor, Daily Post, Fiji Times, September 1. Daily Post (1998a). "Bole slams Robie", September 1.

Daily Post (1998b). "Attack on journalists", editorial, September 1.

Daily Post (1998c). "Bole denies query into foreign journos", September 9.

Dufflos, Christophe (1998). "The International Federation of Journalists and the Digital

Revolution", in Freedom of Expression and New Communication Technologies,

Collection Collectif, Quebec, Canada.

Evening Post, NZ (1998). "University backs beleagured NZ journalists", September 2. Fiji Times (1998a), "Lecturers work permits queried", by Margaret Wise, p3, August 27. Fiji Times (1998b). "Work permits under probe," by Margaret Wise, p 3, August 28. Fiji Times (1998c). "A draconian response," editorial, August 31.

Godwin, Mike (1998). "Freedom of expression and the virtual community", in Freedom

of Expression and New Communication Technologies, Collection Collectif, Quebec, Canada.

Goldstein, Tom (1985). The News at Any Cost: How Journalists Compromise Their Ethics to Shape the News, Simon and Schuster, New York.

Hampande, Douglas (1998), "Internet row over newspaper's reporting style", Misanet, December 10; republished Asia-Pacific Network, January 2, 1999.

Honimae, Johnson (1992). "People's Forum: The way it happened", Solomon Star, March 18.

Hooper, Robert A. (1998). “An Internet-driven national transition", Los Angeles Times, November 23.

New Zealand Herald (1994). Magazine 'invented drink idea', April 22.

New Zealand Herald (1998). "Fiji presses for work ban to muzzle NZ duo", September

2.

100 PACIFIC JOURNALISM REVIEW 6:12000 


\section{ONLINE CENSORSHIP}

Parkinson, William (1998). Statement by the president of the Pacific Islands News Association (PINA), September 1.

Quinn, Stephen (1998). An open letter discussing Pacific Journalism Online, November 23 .

Reddick, Randy, and King, Elliot (1997). The Online Journalist: Using the Internet and other Electronic Resources, Fort Worth, Texas, Harcourt Brace College Publishers. Reportage Media Magazine (1998), "Press freedom on the rocks", by David Robie, Spring, pp 14-15. (The original article which was later posted on the web at Café Pacific). http://www.asiapac.org.fi/cafepacific/resources/aspac/pacmedia.html

Reporters Sans Frontières (RSF) (1998). Letter to Senator Filipe Bole by RSF general secretary Robert Ménard, August 31.

Robie, David (1997). "Hot-wired Pacific media", Pacific Journalism Review, 4:1,

November.

- (1998a). "The Internet and Journalism Education in the South Pacific," Commonwealth Editors' Forum, Penang, Malaysia, October 21-23.

http://www.usp.ac.fj/journ/docs/taveta/inter.html

- (1998b). Letter to the editor, Fiji Times, August 31.

- (1998c). "The gag threat to Café Pacific", Café Pacific, September 5.

http://www.asiapac.org.fi/cafepacific/resources/aspac/gag.html

Samson, Dominic (1998). Letter to the Daily Post, Fiji Times, November 25.

Tahiti-Pacifique (1998). "Barometre: Orageux", September.

The Word (1992). "Sacking of radio journalist alarming", June.

University of the South Pacific Information Office (1998). Media statement, August 28.

Wickliffe, Caren (1998). Letter to Pacific Journalism Online, September 2.

$\square$ David Robie is Senior Lecturer and Journalism Coordinator at the University of the South Pacific. He teaches online journalism and desktop publishing at USP and established Pacific Journalism Online with his students in 1998. His students' print and online papers, Wansolwara and Spicol Daily, won two honours in the 1999 Ossie Awards for journalism. He is editor of Pacific Journalism Review.This article is revised from a paper presented at the Journalism Education Association (JEA) conference at Yeppoon, Queensland, 1-4 December 1998 under the title "Café Pacific and Pacific Journalism Online: Cyberspace media in an island state". It was first published in the Asia-Pacific Media Educator, Issue 6, January-June 1999. Email: David.Robie@usp.ac.fj 